\title{
THE BACKGROUND IMPACT IN HEI MATH LECTURES - AN EXPERIENCE IN MATH IN THE 1ST YEAR OF ACCOUNTING AND MANAGEMENT DEGREE
}

\author{
Maria Paula Nunes ${ }^{1}$, Filomena Soares ${ }^{1}$, Ana Paula Lopes ${ }^{2}$ \\ ${ }^{1}$ Polytechnic of Porto (P.PORTO) / ESEIG (PORTUGAL) \\ ${ }^{2}$ Polytechnic of Porto (P.PORTO) / ISCAP - CICE / UIE (PORTUGAL)
}

\begin{abstract}
It is a fact, and far from being a new one, that students have been entering Higher Education courses with many different backgrounds in terms of secondary school programs they attended. The impact of these basic skills is a general and worldwide challenge, fundamentally when facing some specific "constructive" subjects like foreign languages and Mathematics.
\end{abstract}

Working with students with an extensive variety of Math qualifications is an outrageous challenge when they enter an advanced Math course, leading to an almost generalized expectations' failure from students enrolled in course and from their teachers, who feel powerless in trying to monitor knowledge construction from completely different "starting points".

If teachers' "haste" is average, more than half of the students do not "go along" and give up, even before experiencing any kind of evaluation procedure. On the contrary, if the "speed" is too low, others are discouraged (feeling not progressing at all) and the teacher runs the risk of not meeting the minimum objectives (general and specific) of its course, which may have a negative impact on students' future training development. Failure in Mathematics, despite being a recurrent and global issue, does not have any "magical solution", however, in general, teachers in this area seem untiring, searching, investigating, trying and implementing new and old "recipes" to tackle and demystify this subject.

In this article we describe a project developed in a Math course, with the first year students from an Accounting and Management bachelor degree, and its outcomes since it was brought to practice, revealing its impact in students' success, from approval to dropout rates, in this course. We will shortly describe students' differentiated Math backgrounds, their results in a pre-assessment analysis and how we try to deal with these differences and level them up, having in mind the same "finish line".

One should never forget that all these students were officially accepted in higher education institutions, so they are ones' reality, the reality of institutions whose name one should value and strive to defend.

Keywords: Educational Experiences, Higher Education, Mathematics Curricula, Personalized Learning, Active Learning, Student Engagement.

\section{INTRODUCTION}

The School of Management and Industrial Studies (ESEIG) is one of the seven Organic Units (OU) from the Polytechnic of Porto (P.PORTO) whose trademark was renewed in February 2016, leaving the usual IPP acronym (Polytechnic Institute of Porto) for Polytechnic of Porto (P.PORTO). With a history of more than 25 years, ESEIG "aimed at the education of technical staff for managerial and technological areas, as well as at the creation of solid links with the social-economic surroundings and promoting the regional development - a specific vocation of Polytechnic Institutes in Portugal" [1], an important task due to its regional characteristics since it is about $40 \mathrm{~km}$ from Oporto city center, in the region across the counties of Póvoa de Varzim and Vila do Conde. With a training offer of eight Bachelor degrees, seven Post-graduate programs, seven Master's degrees, and two Post-secondary Specialization Programs, in areas that go from Accounting and Management (the first degree), to Design, Hotel Management, Human Resources, Engineering, among others, ESEIG has about 1,500 students and more than 100 teachers.

When it comes to the "oldest" degree in our OU, it already has experienced several changes to its curriculum, with the most notable being when the adaptation to the Bologna Process, in 2006. In these modifications, non-nuclear areas are usually the most "punished", essentially when it comes to the 
number of contact hours (lectures). Regarding Mathematics, specifically, a reduction from 6 to 3 weekly hours was felt from 2001 to 2006 (until now), but this adjustment was not directly followed by a reduction in the syllabus content.

Another problem arose from establishing the minimum grade for the entry test (Specific Exam) to 9,5 in a 0 to 20 scale, in the academic year of 2005/2006 ([2], [3]). This decision, although a correct one in our opinion, carried out a huge drop in the number of students that entered into courses witch the Specific Exam required was Mathematics A (National Exam). In that sense, many institutions made remarkable changes to the Specific Exam required to enter in their degrees, and in our OU one of these was the Accounting and Management degree. In particular, until 2006, in the Accounting and Management Degree we accepted students who have taken the following entry exams: Economy; Geography and Mathematics A [4]. Since 2007 until today the Specific Exams accepted are: Economy, Portuguese and Mathematics Applied to Social Sciences (Matemática Aplicada às Ciências Sociais - MACS) [4]. One must notice that, this last exam admits its grade to be exchanged by the grade obtained in Mathematics A or Mathematics B Exam, fact that did not happen when the Math Exam accepted for entry in ESEIG was Math A (in this case only the grade obtained in that specific exam was admitted).

There have been some "problematic" years concerning grades in the National Specific Exams, as it can be seen in several news ([5], [6], [7]). Whenever an intensive drop in students achievements in the Specific Exams happens, all the superior scholar system reflects these drips. For example, in 2011 the average grade in Mathematics A exam (the specific test for those who apply to engineering degrees, among others) did not exceed the eight points, the average in Mathematics B was 7.4 points and in Portuguese 9.1 points. Even in a direct subject related to the degree area like Economy the grades seem to be "continuously" dropping (see [8]).

Despite all information available it is not easy to determine which of the required Exams students use for their entrance grade in Higher Education Institutions (HEI) - this grade is a pondered average of their secondary studies (three years) and the Specific Exam they choose from "list", that is, as already mentioned, for the bachelor degree in study, are: 04 Economy, 18 Portuguese and 17 MACS (see Table 1 - to clarify the difference between Entrance Tests with the corresponding codes and exams to be performed [9]). Note that the Specific Exam performed is not directly related to the Secondary School Area, for example, a student may enter with Portuguese from any area of studies, in that sense the student's area of studies does not determine their Specific Exam for entering higher education.

Table 1 - Entrance Tests and Exams to be performed to enter Portuguese HEI

\begin{tabular}{|c|c|c|c|c|c|c|c|}
\hline \multicolumn{2}{|c|}{ Entrance Tests } & \multicolumn{2}{|c|}{ Exams to Perform } & \multicolumn{2}{|c|}{ Entrance Tests } & \multicolumn{2}{|c|}{ Exams to Perform } \\
\hline 01 & German & 501 & $\begin{array}{l}\text { German (initiation } \\
\text { - Biennial) }\end{array}$ & 02 & $\begin{array}{l}\text { Biology } \\
\text { Geology }\end{array}$ & 702 & $\begin{array}{l}\text { Biology and } \\
\text { Geology }\end{array}$ \\
\hline 03 & Drawing & 706 & Drawing A & 04 & Economy & 712 & Economy A \\
\hline 05 & Spanish & 547 & $\begin{array}{l}\text { Spanish (initiation } \\
\text { - Biennial) }\end{array}$ & 06 & Philosophy & 714 & Philosophy \\
\hline 07 & $\begin{array}{l}\text { Physics and } \\
\text { Chemistry }\end{array}$ & 715 & $\begin{array}{l}\text { Physics and } \\
\text { Chemistry A }\end{array}$ & 08 & French & 517 & $\begin{array}{l}\text { French } \\
\text { (continued - } \\
\text { Biennial) }\end{array}$ \\
\hline 09 & Geography & 719 & Geography A & 10 & $\begin{array}{l}\text { Descriptive } \\
\text { Geometry }\end{array}$ & 708 & $\begin{array}{l}\text { Descriptive } \\
\text { Geometry A }\end{array}$ \\
\hline \multirow{2}{*}{11} & \multirow{2}{*}{ History } & 623 & History A & \multirow{2}{*}{12} & \multirow{2}{*}{$\begin{array}{l}\text { History of Culture } \\
\text { and Arts }\end{array}$} & \multirow{2}{*}{724} & \multirow{2}{*}{$\begin{array}{l}\text { History of } \\
\text { Culture and } \\
\text { Arts }\end{array}$} \\
\hline & & 723 & History B & & & & \\
\hline 13 & English & 550 & $\begin{array}{l}\text { English (continued } \\
\text { - Biennial) }\end{array}$ & 14 & Latin & 732 & Latin A \\
\hline \multirow[t]{2}{*}{15} & \multirow{2}{*}{$\begin{array}{l}\text { Portuguese } \\
\text { Literature }\end{array}$} & \multirow[t]{2}{*}{734} & \multirow{2}{*}{$\begin{array}{l}\text { Portuguese } \\
\text { Literature }\end{array}$} & \multirow{2}{*}{16} & \multirow{2}{*}{ Mathematics } & 635 & Mathematics A \\
\hline & & & & & & 735 & Mathematics B \\
\hline \multirow{3}{*}{17} & \multirow{3}{*}{$\begin{array}{l}\text { Mathematics } \\
\text { Applied to Social } \\
\text { Sciences }\end{array}$} & 635 & Mathematics A & \multirow{3}{*}{18} & \multirow{3}{*}{ Portuguese } & \multirow{3}{*}{$\begin{array}{l}639 \\
239\end{array}$} & \multirow{3}{*}{$\begin{array}{l}\text { Portuguese } \\
\text { Only for severe } \\
\text { deaf }\end{array}$} \\
\hline & & 735 & Mathematics B & & & & \\
\hline & & 835 & MACS & & & & \\
\hline 19 & Mathematics A & 635 & Mathematics & & & & \\
\hline
\end{tabular}




\subsection{Some results from National Application Process $\left(1^{\text {st }}\right.$ Stage $)$ in accessing Accounting and Management degrees}

Almost all the data presented in this section are on public domain [10].

\subsubsection{Accounting and Management degree in ESEIG}

In the next figures it is presented the original fields of study that students enrolled in Mathematics course came from, in the last three years. Globally speaking, as Fig. 1. and Fig. 2 show, there are not almost any differences between the overall candidates' area and the area of those who manage to enrolled this degree. But the challenge to be faced, despite being related to the field of study, just to go a little beyond this issue, since the Specific Test used for entering this degree was not, frequently, the Mathematics A exam.

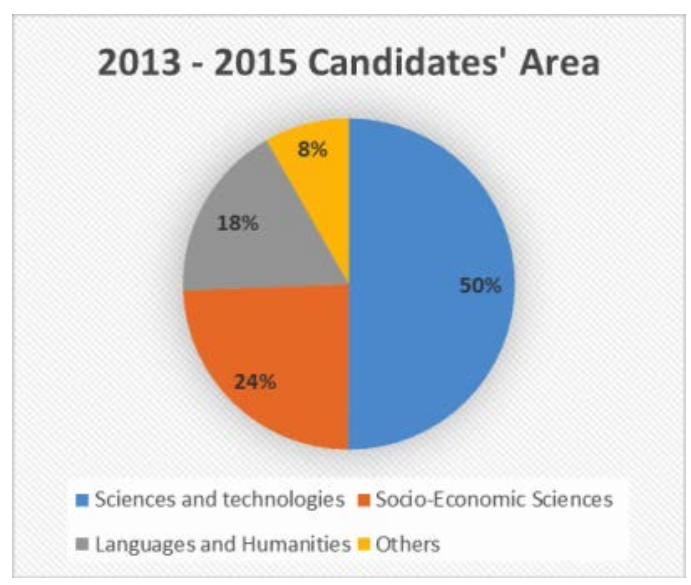

Figure 1 Study area of all the candidates to Accounting and Management

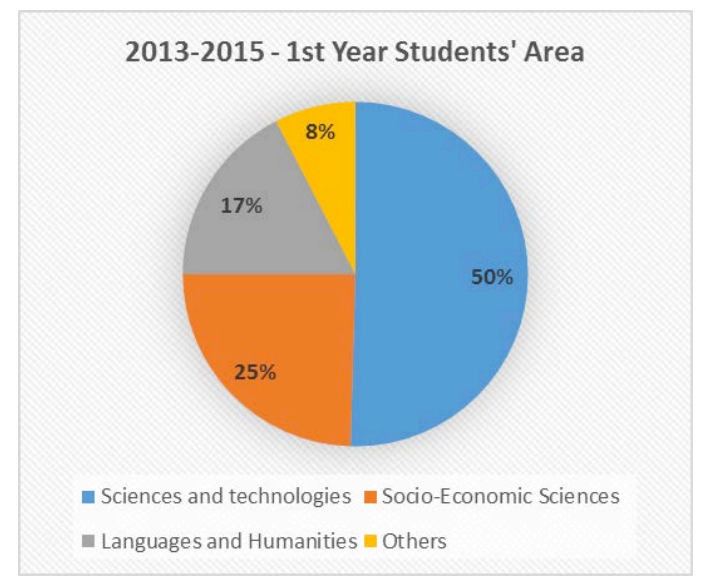

Figure 2 - Study area of the students enrolled in Accounting and Management

Looking at Fig. 2, we can see that $75 \%$ of students attended the areas of Science and Technology and Socio-economic Sciences, however, as you can see in Fig. 3 only 26\% used Mathematics A National Exam as Entrance Examination. This information was retrieved from the data obtained in an annual enquiry that all students entering Accounting and Management degree at ESEIG have been answering, in the school Moodlle platform since 2013, developed by their Math teachers. It seems to be the only way to access this type of information, not available in any public data base that we know of.

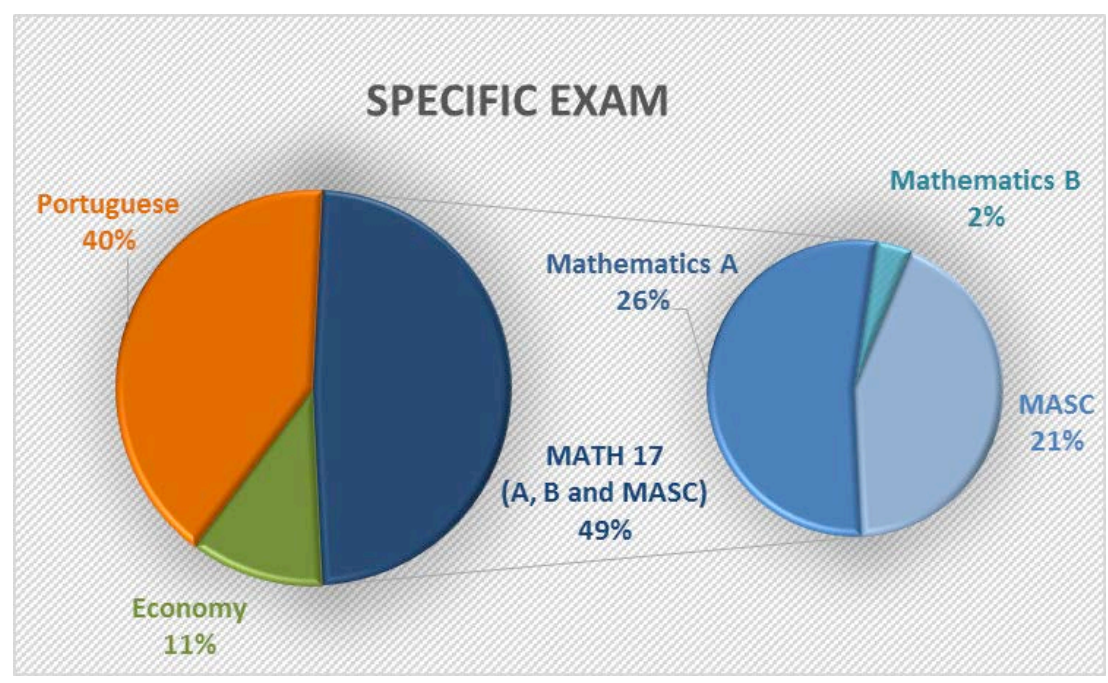

Figure 3 - National Exam - Accounting and Management ESEIG 2015 


\subsubsection{Math Syllabus in Portuguese Secondary School}

To give just a glance of the difficulties that this different Math basic skills confront us, one must take a small look into the contents in the Mathematics curricular unit these students have in the first semester of the first year of the Accounting and Management degree (see Fig. 4) and into the programs and curricular targets of the three possibilities of Mathematics in Secondary Education Portuguese system.

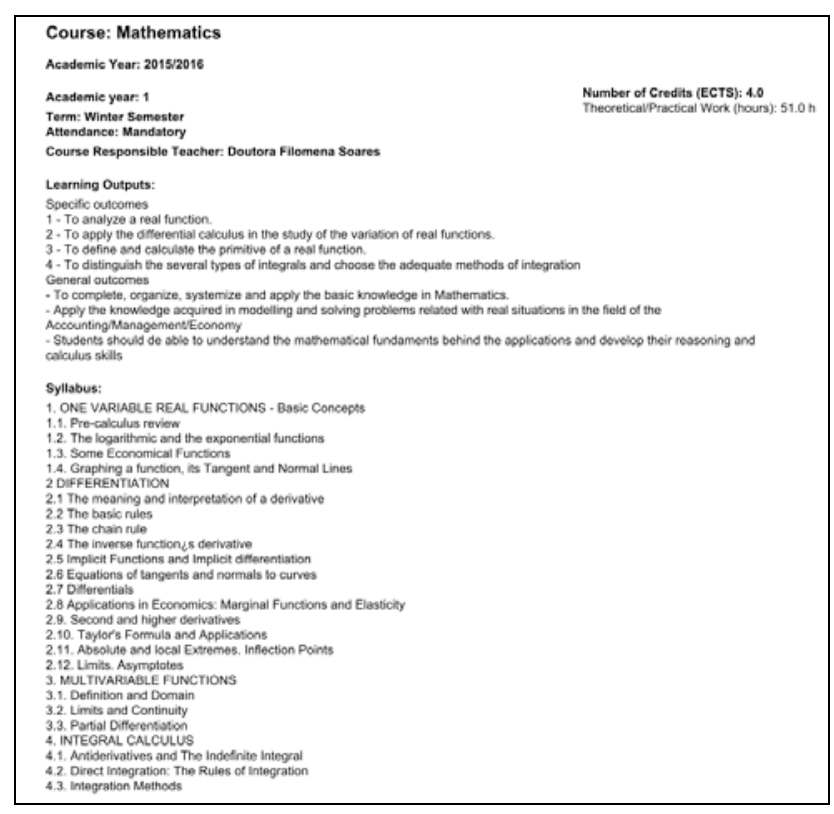

Figure 4 - Mathematics Course Syllabus (excerpt)

Regarding MACS, being just a two year course $\left(10^{\text {th }}\right.$ and $\left.11^{\text {th }}\right)$, its contents are, obviously, "shorter" than those of a three year one, like Math $A\left(10^{\text {th }}, 11^{\text {th }}\right.$ and $\left.12^{\text {th }}\right)$, with the aggravating circumstance of MACS having less weekly working hours. Even the specific contents are quite different, beginning in the 10th year with Decision Support Methods - Mathematical Theory of Elections, Statistics and Financial Models, addressing the 11th year, Population Models and Graphs Models, passing through Probability Models and ending with Introduction to Statistical Inference.

In what concerns the Mathematics $B$, although this is present in the three school years, the weekly schedule (3h) is almost half of Mathematics A (5h), which implies that the subjects are often covered without the necessary "deepness". The issues in question are various, starting in the $10^{\text {th }}$ grade with Geometry in the Plane and Space, Functions and Graphs - General - Polynomial Functions and Statistics, passing through Periodical Movements and Non-linear Movements, where the Rational Functions are addressed $\left(11^{\text {th }}\right)$. The subjects end addressing Probability Models, Discrete Models (sequences), Non-linear Continuous Models (exponential and logarithmic), finishing with Optimization Problems.

Regarding the Mathematics A contents, the subjects are covered in more depth and there is a greater concern for scientific rigor. Thus, in a similar minimalistic way, the program comes down to the following main points along the three years: Geometry in the Plane and in Space $\left(10^{\text {th }}\right.$ and $\left.11^{\text {th }}\right)$; Analytic Geometry; Function and Graphics: generalities about functions; Descriptive and Inductive Statistics; Introduction to Differential Calculus - Rational and Radical functions, Exponential and Logarithmic Functions $\left(11^{\text {th }}\right.$ and $\left.12^{\text {th }}\right)$; Rate of change and Derivative Function $\left(11^{\text {th }}\right.$ and $\left.12^{\text {th }}\right)$; Real Sequences $\left(11^{\text {th }}\right)$; Probability and Combinatorics $\left(12^{\text {th }}\right)$; Trigonometry and Complex Numbers $\left(12^{\text {th }}\right)$.

With such different competences, being developed in secondary school, dealing with these differentiated backgrounded "minds" is not an easy task to teach Mathematics to students with so different backgrounds.

It is not possible to move forward without mentioning that all these "stresses" are a common feeling among many HEl. Speaking only about the bachelor degree in Accounting and Management in Portugal, it is important to look "aside", that is, what is happening in "neighbor" degrees? Well, as it is accessible to anyone interested in these matters, we can look for some insights. 


\subsection{Accounting and Management degrees in Portugal}

Although not having access to the real Specific Test that candidates used to enter these Degrees, the following information just distinguishes the Specific Test required to enroll these any degrees in Accounting/Administration Area. First, in Table 2, it is shown the list of available degrees (directly related to Accounting) offered by Portuguese Public Education sector and its regional distribution can be seen in Fig 5. Notice that there are several degrees in Accounting that registered less than twelve students in the $1^{\text {st }}$ stage of the National application process, for example, in 2013 the Polytechnics of Guarda and Viseu, registered just one candidate entering this Degree in this first stage of the selection process.

Table 2 - Bachelor Degrees in Accounting Area - Portugal 2015

\begin{tabular}{|c|c|}
\hline Degree Designation & Institution \\
\hline $\begin{array}{l}\text { Finance and } \\
\text { Accounting }\end{array}$ & ISCTE - Lisbon University Institute \\
\hline Accounting & School of Accounting and Administration of Aveiro \\
\hline Accounting & $\begin{array}{l}\text { Polytechnic of Cávado and Ave - School of } \\
\text { Management }\end{array}$ \\
\hline Accounting & School of Technology and Management of Bragança \\
\hline Accounting & $\begin{array}{l}\text { Polytechnic Institute of Guarda - School of } \\
\text { Technology and Management }\end{array}$ \\
\hline $\begin{array}{l}\text { Accounting and } \\
\text { Management }\end{array}$ & School of Accounting and Administration of Lisbon \\
\hline $\begin{array}{l}\text { Accounting and } \\
\text { Management }\end{array}$ & School of Accounting and Administration of Porto \\
\hline $\begin{array}{l}\text { Accounting and } \\
\text { Management }\end{array}$ & $\begin{array}{l}\text { Polytechnic Institute of Porto - School of Industrial } \\
\text { Studies and Management }\end{array}$ \\
\hline $\begin{array}{l}\text { Accounting and } \\
\text { Management }\end{array}$ & School of Accounting and Administration of Coimbra \\
\hline $\begin{array}{l}\text { Accounting and } \\
\text { Management }\end{array}$ & School of Technology and Management of Lamego \\
\hline $\begin{array}{l}\text { Accounting and } \\
\text { Finance }\end{array}$ & $\begin{array}{l}\text { Leiria Polytechnic Institute - School of Technology } \\
\text { and Management }\end{array}$ \\
\hline $\begin{array}{l}\text { Accounting and } \\
\text { Finance }\end{array}$ & $\begin{array}{l}\text { Setúbal Polytechnic Institute - School of Business } \\
\text { Administration }\end{array}$ \\
\hline $\begin{array}{l}\text { Accounting and } \\
\text { Taxation }\end{array}$ & School of Technology and Management of Santarém \\
\hline $\begin{array}{l}\text { Accounting and } \\
\text { Financial Management }\end{array}$ & School of Management of Idanha-a-Nova \\
\hline $\begin{array}{l}\text { Accounting and Public } \\
\text { Management }\end{array}$ & School of Accounting and Administration of Coimbra \\
\hline
\end{tabular}

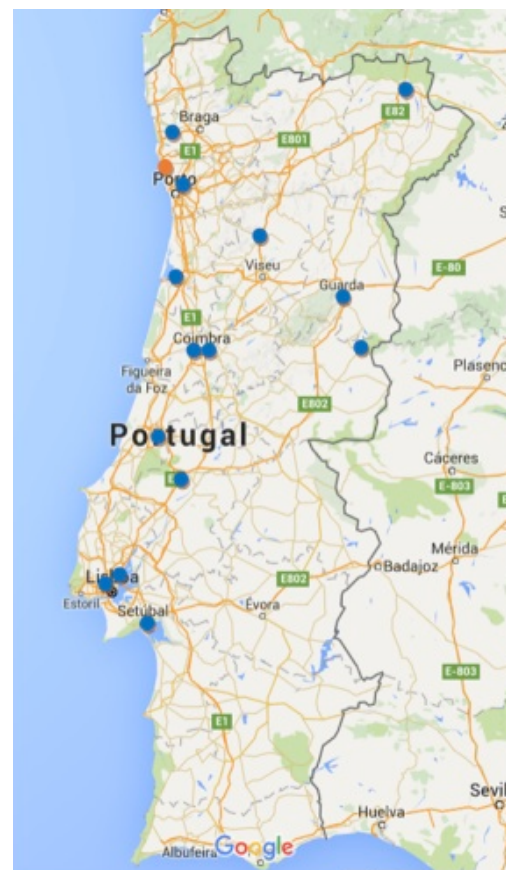

Figure 5 - Regional Distribution of Accounting Area Bachelor Degrees

Considering these fifteen degrees, we must note that only one (from ISCTE) requires Math A ("19 Math" National Exam) in order to enter this course. The other fourteen degrees open their doors to almost every area in Portuguese secondary education, since the specific exams required are mainly the same as in our case (see Fig. 6). Notice also that "16 Math" exam accepts grades from Math A and Math B exams, while "17 MACS" accepts grades from all Math exams (A, B and MACS) and exams like "18 Portuguese" and "09 Geography" has a wide range of secondary areas attained.

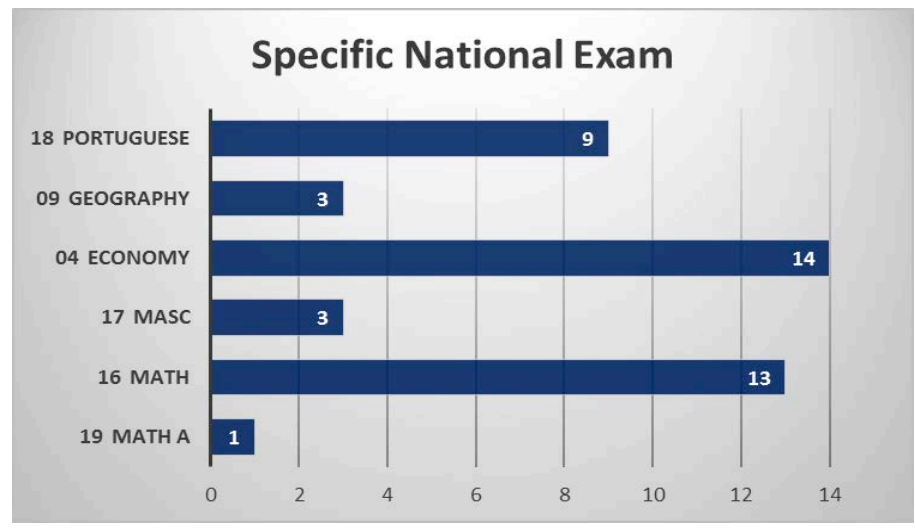

Figure 6 - Specific Exams needed to enter a Bachelor Degree 
So, we think it is licit to think that the problems we have been experiencing, with the substantial differences in Math background competences of our students, for the past few years are, at least, a national one and, unfortunately, we don't hear much "comments" over that issues.

When we are face to face with an audience feeling that for half of them we speak "Chinese", and for the other half, it seems that we are talking with five years of delay (a kind of "ABC" to someone who reads fluently) and confronted with some unsuccessful assessment rates, being "teaching lovers" we felt it was important to try to revert something in this global process.

\section{MEASURE PROPOSAL TO COMBAT FAILURE AT MATH COURSE OF THE DEGREE IN ACCOUNTING AND ADMINISTRATION}

This proposal has been yearly presented at the Department of Mathematics of ESEIG and submitted after to the Technologic-Scientific Council, in order to be approved, since 2012. Since that year, it has been functioning, despite all the financial constraints that we have been trough. The responsible for the Mathematics Curricular Units in this degree $\left(1^{\text {st }}\right.$ and $2^{\text {nd }}$ academic years), came to propose the maintenance this measure, which we will briefly describe in this section, reducing one class in the first semester of second year of this degree, in the course of Probabilistic Methods (working with more than 70 students), which allows to annually perform this workload duplication without increasing the number of needed teachers for courses affected the department.

\subsection{Fundamental reasons to propose this Measure}

A very large number of students (more than $1 / 3$ as we have already mentioned) registered in the first year course of Mathematics of the Accounting and Management Degree and the vast majority of repeating students joined this Bachelor Degree without attending Mathematics (A or B) in secondary education. This is in addition to the 9th grade, these students only have, on its academic curriculum eventually the Curricular Units (CU) Quantitative Methods or Mathematics Applied to Social Sciences (MACS), existing in the 10th year. Note also that this $9^{\text {th }}$ grade was, at least, completed three years before entering to our school (and "fled Mathematics" in secondary education, there will certainly be an underlying obvious reason - struggling with difficulties in this subject).

As we tried to investigate the general lack of motivation in these students, in a CU where the use of basic concepts is constant, was fundamentally due to the fact that they could not keep up with all the new or even "revision" themes, feeling unable to work these concepts in an autonomous way. So, in a sense, the proposed measures were attempting to provide a type of "more targeted education" to the general and specific gaps of those students who enter without having seen (or succeeded) Mathematics in secondary education.

\subsection{Proposed Methodology}

This proposal was based on concrete facts and actual findings, as reflected in the vast experience of lecturers that teach this course for more than ten years, always trying to implement new strategies and monitor their results.

All the students enrolled at the $\mathrm{CU}$ of Mathematics for the first time was submitted to a Diagnostic Evaluation Test before the actual start of the working classes (date always officially marked and transmitted to students in their inscription moment - this date has always been, in the past three years, in the early morning of the first day of classes).

According to the grades obtained in the diagnostic test, which were posted prior to enrollment in classes, students were advised to choose one of the 3 options:

- Advised to attend class with 3 weekly contact hours;

- Advised to attend class with 6 weekly contact hours and

- At the student criteria

In the last three years, since this Test has been settled in ESEIG Moodle Platform, students have an automatic feedback of their answers and, accordingly to their grades, they receive the advices cited. Note that, these are only advices and no one was/is ever forced or compelled to engage a class against their will. The grades from this Diagnostic Test were never taken in consideration by any teacher in any moment, in an individual level, since their purpose is only for the students benefit and these are anonymously answered. 
In 2011 it was tried another methodology, offering students 3 extra hours of accompanied work but, as there was not any previous commitment from them, the audience/assistance was always very volatile in these extra-hours class. With this behavior we felt the objectives of these hours were far from being accomplished, too little was done to overcome students' differences in Math background competences. During all the semester only 3 students attend these extra-hours with a frequency over $75 \%$ of classes attended. In this sense we had to try to change something, if we really wanted to make some difference.

When classes start, all students, committed to an effort oh 6 weekly hours, assumed that from September to January they will assist these hours. With the "doubling" of the course load, it enables a differentiated management of content covered in the CU subject, facilitating the "revision" of many issues addressed in secondary education. Thus we try some kind of leveling "up" knowledge and skills, always trying to fulfill the program set in the syllabus.

\subsection{Assessment in the Mathematics Course}

There is a constant concern, from the teachers of this course, for the development of well differentiated pedagogical practices, providing students all the various materials in digital form, promoting their use in sequence and according to the needs of each group/class.

The assessment in this $\mathrm{CU}$ is performed through two moments of classroom assessment (two tests) with different weights and several small tests online (implemented in ESEIG Moodle Platform), distributed throughout the semester in order to promote a "true" continuous evaluation and monitoring continuous learning results.

It is important to mention that the first moment of classroom assessment is performed when have passed about $2 / 3$ of the Term weeks (not the middle of the semester) to enable the realization of the same test for all students enrolled at CU regardless of number of class contact hours that they attend.

Usually, the learning objectives (see Fig.4) for the first test are items 1 to 3, leaving for the second only item 4 - Integration. As the degree central areas are Accounting, Management and Economy, we try to focus all the problems in applications to these ones, whenever possible, and when reviewing secondary school subjects we practically "pass over" Trigonometry, Trigonometrical Functions and Complex Numbers, in order to accomplish in two months "leveling up schedule".

\subsection{Diagnostic Test Results}

Although the test results are "mute", in the sense that the diagnostic test detailed analysis goes beyond the scope of this article, we present in Fig. 7, the percentage results in the three years in analysis - 2013 to 2015 . Since it has been composed of the same questions and feedback in the years here presented we must notice a dropping tendency in these global results. Though we have the results from a Diagnostic Test in 2012 (done and corrected in paper) we do not present them since the questions in stake were not the same and, as so, the corresponding results fail to be compared.
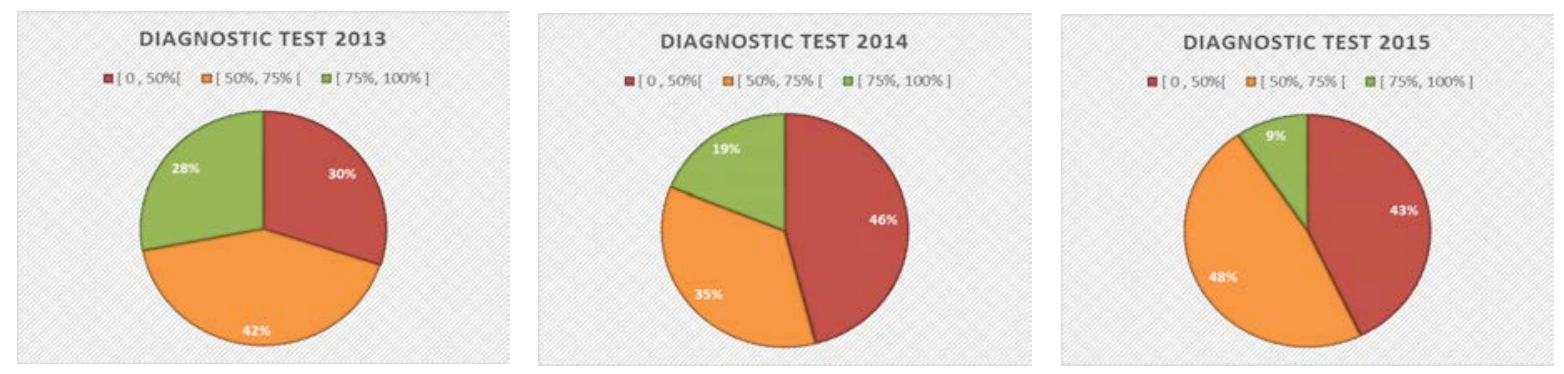

Figure 7 - Diagnostic Test results per year (2013-2015)

These results led to the correspondent feedback, mentioned in section 2.2 in this article:

Advised to attend class with 6 weekly contact hours;

Advised to attend class with 3 weekly contact hours;

At the student criteria. 


\subsubsection{Freshmen and Non-freshmen choices - number of contact hours}

Since students can choose their own schedule, from the three classes available in the beginning of the semester (2 with 6 weekly contact hours and one with 3), we present in Fig. 8 and 9 their choices note that, for Fig. 8, we withdraw from the total of registered students the "repeating" students, but in Fig. 9, we show the inscriptions non-freshmen in these different classes, in order to distinguish reactions to Diagnostic test and students future perceptions.
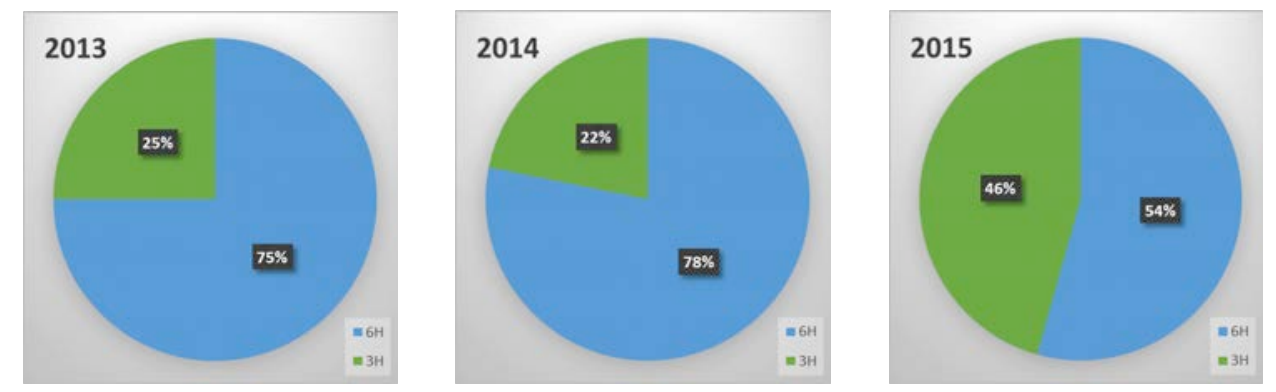

Figure 8 - Freshmen's options - weekly contact hours
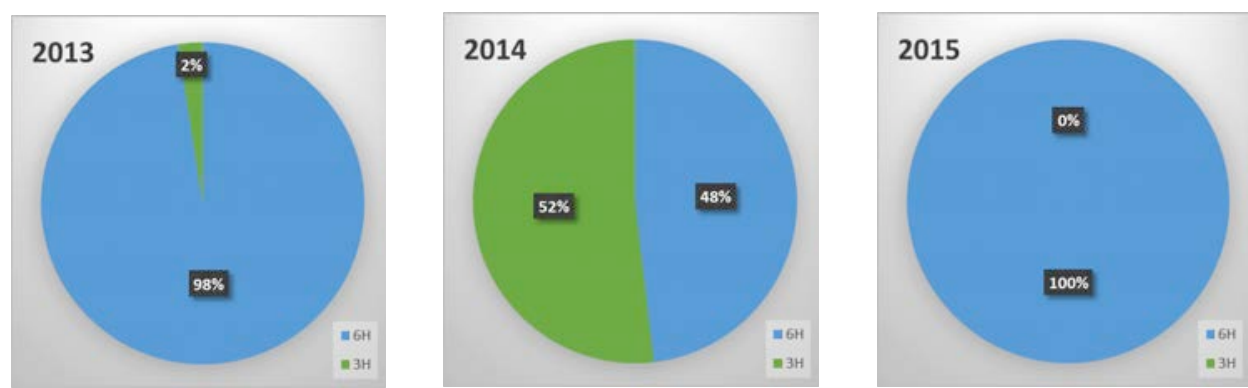

Figure 9 - Non-Freshmen's options - weekly contact hours

The non-freshmen options are quite different, but there are several factors to take notice of - usually even when registered in a 3 hour contact class, if they can they assist to 6 hours. On the other hand, sometimes schedules are not completely compatible with other years' courses and they don't get to assist as often as they should. Notice that these students are, mostly speaking, very conscious of their competences and seek to overcome their difficulties, principally if they feel someone cares.

\section{ASSESSMENT RESULTS - SOME INSIGHTS}

In view of the common old saying that "Use a picture. It's worth a thousand words.", we will essentially present some of the results obtained in Mathematics CU, by Accounting and Management Degree in ESEIG. We will try to analyze their evolution over the past few years, relating these, when possible, with the measures implemented to combat failure. In Fig. 10 we can visualize the evolution of three indicators, globally speaking:

- Relation between Enrolled students (I) and Assessed ones (A), in the percentage $A / E$;

- Relation between Successful students (S) and Assessed ones (A), in the percentage S/A;

- Global relation between Successful students $(S)$ and Enrolled ones (E), in the percentage S/E.

If, in the last three years, we detached our analysis in terms of number of hours of each class, we can see the results transmitted through Fig. 11. 


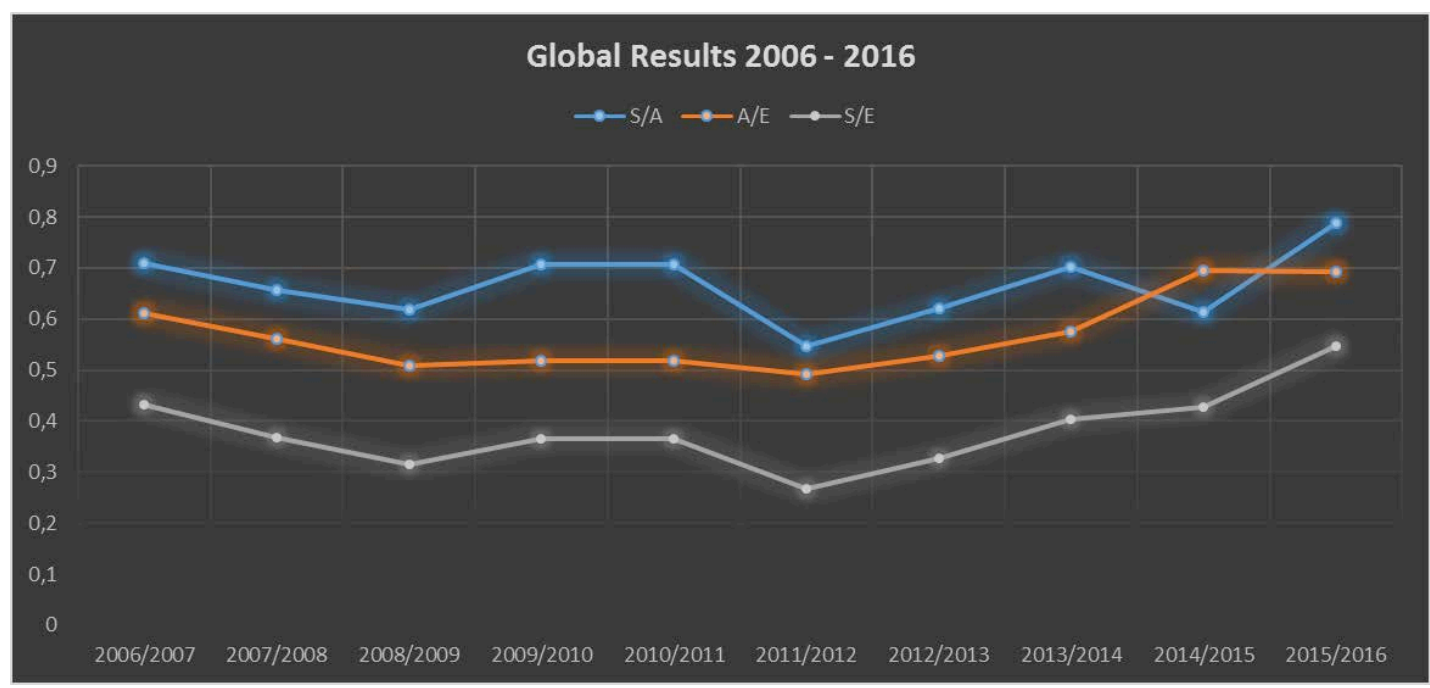

Figure 10 - Assessment indicators - Mathematics

Although there are many issues that imply these results, some of these external, we noticed among others: With the changes made in the criteria to enter this high school program in 2005/2006, its impact is shown in a visual and continuous drop of all indicators (2006-2009). The small raising movement in the two following years is closely connected to the fact that many students were finishing this program after the Bologna adaptation process, struggling to get their degrees. Note that, since many courses have changed from academic year and a new different courses appeared, the transition process has impact over the number of years that students took to complete their course. These often fail to end the courses of mathematics, trying to carry them out only when they have to finish the course.

From a different point of view, this question also justifies, at least part of, the difference between the rates of Successful / Enrolled and Successful / Assessed, which is also one of our concerns.
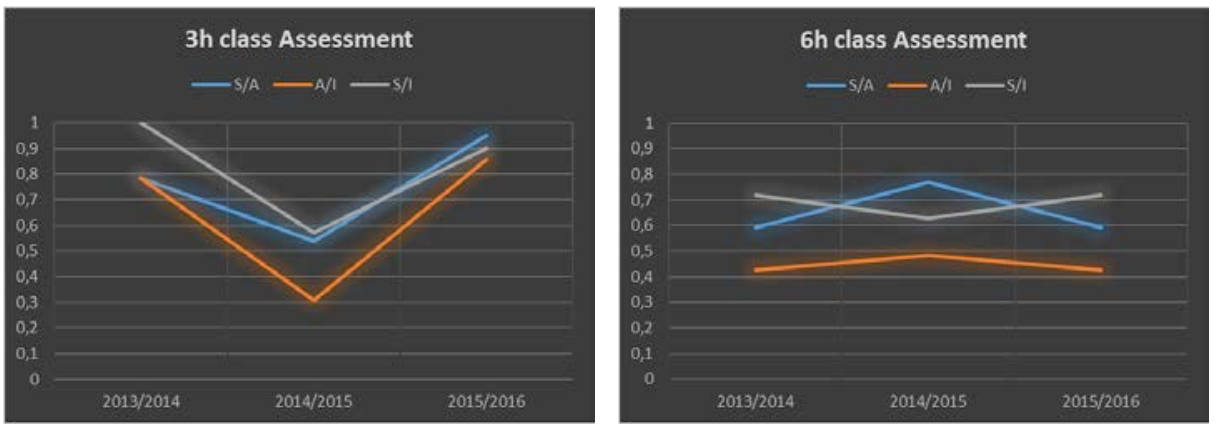

Figure 11 - Assessment rates per number of class contact hours

It is interesting to compare the results shown in this last set of images with the ones on Fig. 7 and 8 . When the number of repeating students in a 3 hour class is high this is directly reflected in the rate drop.

\section{FINAL COMMENTS}

This small venture, implemented in 2012, with registered results since 2013, is in our and students opinion (every year we conducted a satisfaction query among students) a successful one, with a positive assessment feedback.

Despite the positive features presented, there are, obviously, several difficulties to keep in mind: Financial restrictions - These prevent from having an ideal number of students per class. This is a real constraint that affects learning procedures and outcomes when having to work with forty (or even more) students at once, inside a classroom and, simultaneously, try to deal with different learning skills; Frequent high absenteeism rates - this is a fact, essentially, relative to repeaters, some "leave" 
Math courses to last and others struggle to make Math schedules compatible with second and third years courses in order to attend classes; Low motivation to learn - Since Mathematics is a science so unloved in secondary education, it is not easy to reverse "feelings", so common, due to effective areas from which these students come from.

As we have already mentioned, the "weak" training mathematics that many students have received is a fact, but another fact is that we accept them and therefore they are our reality, the reality of our school from the P.Porto. Like plan this has its fails, not exempt of objections and obstacles either in its implementation or in its pursuit, however, the development of a conscientious work is not possible when we notice students' difficulties without, at least, trying to do something.

\section{REFERENCES}

[1] School of Management and Industrial Studies (ESEIG), https://www.eseig.ipp.pt/en/

[2] DGES - Legislação. (n.d.). Retrieved April 15, 2016, from http://www.dges.mctes.pt/DGES/pt/Estudantes/Acesso/ConcursoNacionalPublico/Legislacao/ see "Decreto-Lei n. ${ }^{\circ}$ 26/2003, de 7 de fevereiro"

[3] Governo mantém 9,5 como nota mínima de acesso ao ensino superior. (2005, April 22). Retrieved May 01, 2016, from https://www.publico.pt/educacao/noticia/governo-mantem-95como-nota-minima-de-acesso-ao-ensino-superior-1221405

[4] DGES - Aquiver. (n.d.). Retrieved May 1, 2016, from http://www.dges.mctes.pt/DGES/pt/Estudantes/Acesso/ConcursoNacionalPublico/Guias/Arquiv ol

[5] Candidaturas - Médias para o ensino superior podem descer este ano. (2011, August 10). Retrieved April 25, 2016, from http://www.dn.pt/dossiers/tv-e-media/revistas-deimprensa/noticias/interior/medias-para-o-ensino-superior-podem-descer-este-ano-1949517.html

[6] Número de colocados na primeira fase do ensino superior volta a descer. (2012, September 09). Retrieved May 1, 2016, from http://www.rtp.pt/noticias/educacao/numero-de-colocados-naprimeira-fase-do-ensino-superior-volta-a-descer_n585517

[7] Exames do Secundário: Média sobe a Português e desce a Matemática. (2014, July 14). Retrieved April 21, 2016, from http://www.educare.pt/noticias/noticia/ver/?id=28062

[8] Economia: Sempre a descer. (2014, November 13). Retrieved May 1, 2016, from http://visao.sapo.pt/actualidade/sociedade/economia-sempre-a-descer=f802011

[9] DGES - Provas de Ingresso. (n.d.). Retrieved May 01, 2016, from http://www.dges.mctes.pt/DGES/pt/Estudantes/Acesso/ConcursoNacionalPublico/Provasdelngr esso/provasingressoexames.htm

[10] DGES - Estudos e Estatísticas. (n.d.). Retrieved April 15, 2016, from http://www.dges.mctes.pt/DGES/pt/Estudantes/Acesso/Estatisticas/EstudosEstatisticas/ 